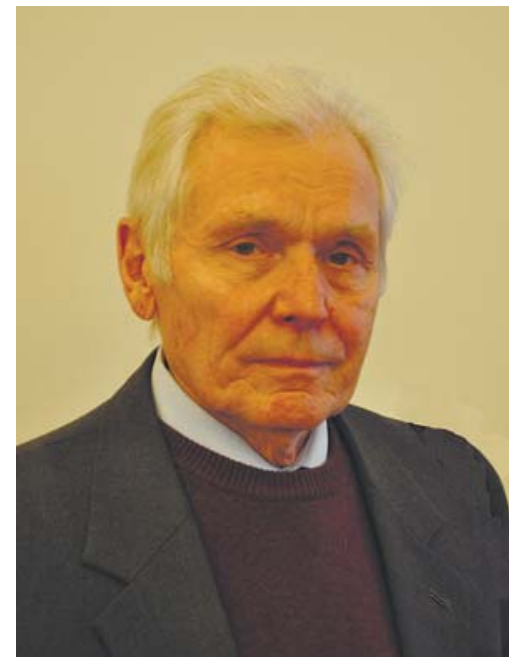

СТАРОСТЕНКО

Віталій Іванович академік НАН України, директор Інституту геофізики ім. С.І. Субботіна НАН України, голова Наукової ради цільової програми наукових досліджень НАН України «Мінеральносировинна база України як основа безпеки держави»

\section{ПРО РЕЗУЛЬТАТИ ВИКОНАННЯ ЦЛЬОВОЇ ПРОГРАМИ НАУКОВИХ ДОСЛІДЖЕНЬ НАН УКРАЇНИ «МІНЕРАЛЬНО-СИРОВИННА БАЗА УКРАЇНИ ЯК ОСНОВА БЕЗПЕКИ ДЕРЖАВИ»}

\author{
Стенограма доповіді на засіданні \\ Президії НАН України 3 березня 2021 року
}

У доповіді наведено найважливіші результати виконання цільової програми наукових досліджень НАН України «Мінерально-сировинна база України як основа безпеки держави». Зазначено, що програму було спрямовано на науково-методичну підтримку розвитку мінерально-сировинної бази України та протидію деградацї геологічної галузі, яка критично впливає на економічну, соціально-політичну й геополітичну стабільність та життєзабезпечення населення. 3 метою продовження досліджень запропоновано започаткувати иільову програму наукових досліджень НАН України «Критичні та стратегічні мінеральні ресурси України за умов глобалізаціі та змін клімату» на 2021-2025 рр.

Шановний Анатолію Глібовичу!

Шановні члени Президії! Шановні колеги!

Стан мінерально-сировинної бази України прямо і опосередковано впливає на iĭ економічну, соціально-політичну та геополітичну стабільність, на життєзабезпечення населення країни. Тому дослідження, які проводилися в рамках цільової програми наукових досліджень НАН України «Мінерально-сировинна база України як основа безпеки держави», мали безпосередній стосунок до зміцнення безпеки держави.

Протягом 2016-2020 рр. за програмою виконувалося 27 проєктів (24 - за бюджетною програмою КПКВК 6541030 та у 2019 р. 3 проєкти за бюджетною програмою КПКВК 6541230) за 4 основними напрямами-розділами, визначеними науковою радою програми. У виконанні проєктів брали участь 16 установ з 5 відділень НАН України, а саме: Відділення наук про Землю, Відділення хіміі, Відділення фізико-технічних проблем енерге- 
тики, Відділення ядерної фізики та енергетики, Відділення інформатики, а також Інститут телекомунікацій і глобального інформаційного простору НАН України. Запровадження міждисциплінарних підходів дало змогу отримати такі найважливіші результати.

Напрям «Наукова підтримка розвитку мінерально-сировинної бази рідкісних, рідкісноземельних металічних корисних копалин та технології переробки комплексних руд». Уперше на основі оновленої концепції геологічної будови надр України, нових тектонофізичних даних, а також із застосуванням методів обробки й інтерпретації геофізичних полів та аномалій побудовано Структурно-петрофізичну карту Побузького гірничорудного району (масштаб $1: 100$ 000). Цю карту використано як основу для прогнозування комплексів корисних копалин.

Розроблено пошукові критерії - як загальнометодичні, так і на конкретні корисні копалини. Загальнометодичні пошукові критерії грунтуються на встановленому факті, що переважна більшість родовищ і рудопроявів корисних копалин Українського щита пов'язана із зонами розломів. Це дало змогу визначити найперспективніші розломні зони в Побузькому гірничорудному районі: Тальнівську, Первомайську, Гайворонську, Заваллівську, Берестягівську, Хмільницьку, Маньківську, а також осьову мантійну частину Голованівської шовної зони, розриви ортогональної системи та вузли перетину розломів тощо. Розроблені пошукові критерії на конкретні рудопрояви і родовища стосуються апатит-фосфатних, титано-ільменітових, легкозбагачуваних залізних руд, хрому, силікатного нікелю, золота та інших благородних металів, рідкісних, рідкісноземельних елементів, графіту, алмазів. Наприклад, пошуковою ознакою скупчень мінералів, які містять рідкіснометальні-рідкісноземельні елементи, зокрема лантан, церій, ітрій, ітербій, є «кишені» залізо-марганцевої кори вивітрювання в детально закартованих широтних розломах і зонах сколювання. Встановлено, що такі зони та «кишені» добре картуються гравімагнітними та геоелектричними методами.
Напрям «Наукове обгрунтування ресурсного забезпечення енергетичної безпеки краіни». Показано, що перспективи нарощування мінерально-сировинної бази Львівсько-Волинського кам'яновугільного басейну пов'язані з освоєнням нових площ і глибоких горизонтів. Зокрема, доведено перспективність освоєння родовищ Південно-Західного вугленосного району як газовугільних родовищ.

Встановлено, що вугільні пласти Тяглівського і Любельського родовищ відрізняються від аналогічних у промисловій частині басейну більшою потужністю і площею поширення, а вугілля цих родовищ має вищу якість і меншу зольність. Доведено, що газове вугілля Тяглівського родовища придатне для коксування. Запаси і ресурси вугілля в районі оцінюються в понад 2 млрд т, що вдвічі перевищує залишкові запаси промислової частини басейну.

Виконання робіт за технологією структурно-термоатмогеохімічних досліджень над гірничими виробками працюючих вугільних шахт Львівсько-Волинського вугільного басейну дало змогу визначити флюїдонепроникні і геодинамічно активні місця як ділянки скупчення вуглеводневих газів та ймовірного виникнення раптових викидів у гірничі виробки. В межах гірничих відводів відпрацьованих вугільних шахт фіксується аномальне розвантаження вуглеводневих газів, що, можливо, приводить до утворення техногенних скупчень, які мають перспективи використання.

Напрям «Водні ресурси України». Проблема забезпечення населення якісною питною водою має велику соціальну значущість, оскільки питна вода безпосередньо впливає на стан здоров’я громадян і є одним з ключових чинників економічної та епідемічної безпеки життєдіяльності людини. Системи централізованого питного водопостачання багатьох регіонів України використовують переважно поверхневі джерела - води Дніпра, Дністра та інших річок, екологічний стан яких останніми роками істотно погіршився.

У результаті виконання Програми було проведено оцінку основних техногенних чинників виснаження і забруднення поверхневих вод

ISSN 1027-3239. Visn. Nac. Acad. Nauk Ukr. 2021. (4) 
на репрезентативних ділянках басейнів Дніпра і Дністра. Визначено рівень екологічного благополуччя їх гідроекосистем, зафіксовано перевищення фонового рівня забруднення i складено перелік основних забруднюючих речовин. Запропоновано стратегію вибору найкращої технології для знешкодження специфічних токсичних і біологічно стійких забруднень стічних вод, на основі якої розроблено низку ефективних технологічних рішень для збереження екологічного благополуччя поверхневих водних ресурсів.

Обгрунтовано необхідність використання альтернативних джерел питного водопостачання населення України - напірних, захищених від прямих надходжень забруднюючих речовин підземних вод, які мають стабільні в часі хімічні, фізико-хімічні та мікробіологічні показники.

Глобальні зміни клімату, що спостерігаються останнім часом, стають новим потужним чинником впливу на питне водопостачання. 3 огляду на це слід зазначити, що підземні води є більш надійним джерелом питного водопостачання, ніж поверхневі, особливо в разі виникнення надзвичайних ситуацій.

Для науково-методичного забезпечення водопостачання в районах, де розвинені тріщинуваті кристалічні породи, оцінюється водоносність розломних зон та можливість залучення ресурсів підземних вод для збільшення дебітів свердловин. Під час виконання одного з проєктів програми за результатами моделювання було встановлено, що основна роль у формуванні експлуатаційних ресурсів підземних вод належить вертикальному перетіканню через роздільний шар кори вивітрювання, а також наявності горизонтального взаємозв'язку 3 підземними водами кристалічного масиву. Отримані результати впроваджено при виборі свердловин двох діючих ділянок Жашківського родовища підземних вод для збільшення продуктивності водозабору.

Розроблено імпульсний метод для відновлення водозабірних свердловин, який грунтується на вибуху суміші газів у спеціальному пристрої з вікнами (газовому генераторі). За- вдяки використанню процесів швидкого горіння та детонації сумішей газів ефективно очищуються закальматовані фільтри свердловин.

Напрям «Розвиток мінерально-сировинної бази неметалічних корисних копалин». Створено базу даних рудопроявів флюориту на території Середнього Придністров’я, складено карту флюоритоносності із зазначенням геохімічної спеціалізації флюоритів як комплексної сировини: поліметалічно-флюоритової (свинець-цинк, мідь), рідкіснометально-флюоритової (літій, ртуть, золото). Визначено перспективні площі флюоритоносності та надано рекомендації щодо доцільності комплексного одночасного видобутку флюориту та інших корисних копалин. Ці рекомендації було прийнято до впровадження у Правобережній геологічній експедиції ДП «Українська геологічна компанія».

Створено інтегровану в ГІС базу даних поширення глауконітвмісних і фосфоритвмісних відкладів на території центральних та західних областей України, яка містить інформацію про 258 та 151 об’єкт відповідно. Глауконіти і фосфорити розглядалися як агрохімічна сировина. Проведено металогенічне районування території за закономірностями поширення глауконітвмісних порід та складено найбільш повний список позабалансових родовищ і проявів. Уперше визначено перелік комплексних і потенційно комплексних родовищ та проявів, одним із корисних компонентів у яких є або може бути глауконіт.

Приклади впровадження результатів досліджень. 3 метою обгрунтування геолого-економічних та еколого-геологічних параметрів безпечного розвитку гірничодобувних районів України вперше було проведено геолого-економічні розрахунки реструктуризації Донецького вугільного і Криворізького залізорудного басейнів в умовах трансформації енергетичної сфери. Розроблено і науково обгрунтовано введення у нормативно-правову базу надрокористування та проведення гірничих робіт положень щодо плати за асиміляційний потенціал територій використання надр. Варто зауважити, що на сьогодні таку плату вже стя- 
гують у деяких країнах Свропейського Союзу. Зазначені напрацювання впроваджено в діяльність Державної комісії України по запасах корисних копалин при проведенні експертизи та затвердженні запасів родовищ з накопиченими порушеннями екологічних параметрів геологічного середовища, а також у діяльність Державної екологічної академії післядипломної освіти та управління.

Загалом за 2016-2020 pр. у результаті виконання програми отримано 12 нових патентів на корисну модель та винахід України, ще 6 заявок на видачу охоронних документів перебувають на стадії розгляду. Отримано 29 актів, листів, довідок про впровадження результатів досліджень. Опубліковано 31 монографію, 124 статті, з яких $94-$ у виданнях, що входять до міжнародних наукометричних баз даних Scopus та Web of Science, 189 матеріалів та тез конференцій.

Результати виконання програми могли б бути й кращими, якби не сучасний стан державної геологічної галузі в Україні, який сьогодні можна назвати вже не просто критичним, а катастрофічним. Перешкодою на шляху ефективного використання надр України є жалюгідне матеріальне становище Державної служби геології та надр України (Держгеонадра України), яка неспроможна організовувати пошукові та розвідувальні роботи і гине на очах. Якщо так триватиме й надалі, то вже незабаром і графіт, і навіть залізну руду ми змушені будемо закуповувати за кордоном, а геологічна зйомка залишиться на рівні 60-70-х років минулого століття.

Невиконання Загальнодержавної програми розвитку мінерально-сировинної бази України на період до 2030 р. призвело до того, що держава втрачає контроль за станом геологічного середовища, відбувається спустошення фонду родовищ і перспективних ділянок корисних копалин; державні геологічні підприємства, що розташовані по всій території України, перебувають на грані виживання, працюють по 2-3 дні на тиждень, а деякі вже збанкрутували.

При цьому Держгеонадра України - центральний орган виконавчої влади, який реа- лізує державну політику у сфері геологічного вивчення та раціонального використання надр, зараз переважно виконує функції, не властиві геологічним службам розвинених країн світу, а саме: надає та анулює спеціальні дозволи на користування надрами, погоджує проєкти на розробку родовищ, здійснює контроль за виконанням надрокористувачами програм робіт тощо. Водночас через мізерні обсяги бюджетного фінансування в Україні майже не проводяться регіональні геологічні дослідження 3 метою створення різномасштабних карт як основи планування всіх видів геологічних, інженерно-геологічних, гірничовидобувних робіт, прогнозування нових ділянок, перспективних на виявлення корисних копалин.

На сьогодні головним видом геологічних робіт в Україні є роботи, спрямовані на створення Державної геологічної карти масштабу 1:200 000 (Держгеолкарта-200) як єдиної основи загального природокористування та раціонального надрокористування, проте розвинені країни світу зараз уже працюють над більш детальним вивченням своїх надр, складаючи карти в масштабі 1:50 000 і крупніше.

Занепад державної геологічної галузі, крім іншого, призвів до втрати матеріально-технічних засобів для геологічного вивчення надр бурових верстатів, геофізичної апаратури, лабораторного обладнання тощо.

На цьому невтішному фоні дослідження, які проводяться за цільовою програмою наукових досліджень Національної академії наук України, є особливо важливими, оскільки забезпечують державу новими, корисними даними про мінеральні ресурси країни. Особливо слід відзначити, що в деяких випадках учені НАН України можуть залучати до виконання проєктів фахівців Державного геофізичного підприємства «Укргеофізика», Державного підприємства «Українська геологічна компанія», що дає змогу об’єднати наші зусилля і разом працювати за окремими темами.

Отже, в рамках виконання цільової програми наукових досліджень НАН України «Мінерально-сировинна база України як основа безпеки держави» отримано низку вагомих на-

ISSN 1027-3239. Visn. Nac. Acad. Nauk Ukr. 2021. (4) 
укових результатів, які сприяють вирішенню актуальних проблем розвитку мінерально-сировинної бази країни, реалізації планів, окреслених Кабінетом Міністрів України у документі «Вектори економічного розвитку до 2030 року». Водночас внаслідок зміни геополітичної ситуації, анексії частини території України відбулися зміни і в мінерально-сировинному комплексі, що має бути оцінено і враховано при обгрунтуванні ресурсного забезпечення економіки держави. Тривала реструктуризація та недофінансування геологічної галузі призвели до їі скорочення.

Вважаємо, що з метою адаптації мінеральносировинної бази країни до сучасних викликів доцільно започаткувати нову цільову програму наукових досліджень НАН України «Критичні та стратегічні мінеральні ресурси України за умов глобалізації та змін клімату», роз- раховану на 2021-2025 рр. Це посилить наукову підтримку геологічного вивчення надр для забезпечення потреб національної економіки у стратегічних та критичних мінерально-сировинних ресурсах, зокрема дозволить обгрунтувати пріоритетні напрями робіт, сприятиме приросту запасів сировини, підтримці власного видобутку корисних копалин, поліпшенню структури мінерально-сировинної бази, i. ефективному використанню за умов глобалізації та змін клімату, а також, можливо, сприятиме реалізації Загальнодержавної програми розвитку мінерально-сировинної бази України на період до 2030 р., яку було затверджено ще в 2011 р., але до виконання якої відповідні державні органи поки що не приступали.

Дякую за увагу!

За матеріалами засідання підготувала О.О. Мележик

Vitaly I. Starostenko

ORCID: https://orcid.org/0000-0002-7960-0011

Subbotin Institute of Geophysics of the National Academy of Sciences of Ukraine, Kyiv, Ukraine

ON THE RESULTS OF THE IMPLEMENTATION OF THE TARGET

RESEARCH PROGRAM OF THE NATIONAL ACADEMY OF SCIENCES OF UKRAINE

"MINERAL RESOURCES OF UKRAINE AS THE BASIS OF STATE SECURITY"

Transcript of scientific report at the meeting of the Presidium of the NAS of Ukraine,

March, 3, 2021

The report presents the most important results of the implementation of the target research program of the NAS of Ukraine "Mineral Resources of Ukraine as the Basis for State Security." It is noted that the program was aimed at scientific and methodological support for the development of mineral resources of Ukraine and combating the degradation of the geological industry, which critically affects the economic, socio-political and geopolitical stability and livelihood of the population. In order to continue research, it is proposed to launch a targeted research program of the NAS of Ukraine "Critical and strategic mineral resources of Ukraine in the context of globalization and climate change" for 2021-2025.

Keywords: mineral resource base, rare earth minerals, non-metallic minerals, energy resources, water resources. 